OPEN ACCESS

Edited by:

Douglas Forrest,

National Institutes of Health $(\mathrm{NIH})$,

United States

Reviewed by:

David B. Allen,

University of Wisconsin-Madison,

United States

Samantha Lain,

The University of Sydney, Australia

${ }^{*}$ Correspondence:

Stephen H. LaFranchi

lafrancs@ohsu.edu

Specialty section:

This article was submitted to

Thyroid Endocrinology,

a section of the journal

Frontiers in Endocrinology

Received: 09 February 2021

Accepted: 24 March 2021

Published: 15 June 2021

Citation:

LaFranchi SH (2021) Thyroid Function

in Preterm/Low Birth Weight Infants:

Impact on Diagnosis and Management of Thyroid Dysfunction.

Front. Endocrinol. 12:666207.

doi: 10.3389/fendo.2021.666207

\section{Thyroid Function in Preterm/Low Birth Weight Infants: Impact on Diagnosis and Management of Thyroid Dysfunction}

\author{
Stephen H. LaFranchi * \\ Department of Pediatrics, Doernbecher Children's Hospital, Oregon Health \& Sciences University, Portland, OR, \\ United States
}

Maternal thyroid hormone crosses the placenta to the fetus beginning in the first trimester, likely playing an important role in fetal development. The fetal thyroid gland begins to produce thyroid hormone in the second trimester, with fetal serum T4 levels gradually rising to term. Full maturation of the hypothalamic-pituitary-thyroid (HPT) axis does not occur until term gestation or the early neonatal period. Postnatal thyroid function in preterm babies is qualitatively similar to term infants, but the TSH surge is reduced, with a corresponding decrease in the rise in T4 and T3 levels. Serum T4 levels are reduced in proportion to the degree of prematurity, representing both loss of the maternal contribution and immaturity of the HPT axis. Other factors, such as neonatal drugs, e.g., dopamine, and non-thyroidal illness syndrome (NTIS) related to co-morbidities contribute to the "hypothyroxinemia of prematurity". lodine, both deficiency and excess, may impact thyroid function in infants born preterm. Overall, the incidence of permanent congenital hypothyroidism in preterm infants appears to be similar to term infants. However, in newborn screening (NBS) that employ a total T4-reflex TSH test approach, a higher proportion of preterm babies will have a T4 below the cutoff, associated with a non-elevated TSH level. In NBS programs with a primary TSH test combined with serial testing, there is a relatively high incidence of "delayed TSH elevation" in preterm neonates. On follow-up, the majority of these cases have transient hypothyroidism. Preterm/LBW infants have many clinical manifestations that might be ascribed to hypothyroidism. The question then arises whether the hypothyroxinemia of prematurity, with thyroid function tests compatible with either non-thyroidal illness syndrome or central hypothyroidism, is a physiologic or pathologic process. In particular, does hypothyroxinemia contribute to the neurodevelopmental impairment common to preterm infants? Results from multiple studies are mixed, with some randomized controlled trials in the most preterm infants born <28 weeks gestation appearing to show benefit. This review will summarize fetal and neonatal thyroid physiology, thyroid disorders specific to preterm/LBW infants and their impact on NBS for congenital hypothyroidism, examine treatment studies, and finish with comments on unresolved questions and areas of controversy.

Keywords: thyroid function, preterm, low birth weight, newborn screening, congenital hypothyroidism, iodine 


\section{INTRODUCTION}

Thyroid hormone plays a significant role in development and function of every organ system in the body. The presence of triiodothyronine (T3) occupied nuclear receptors in the fetal brain demonstrated by 10 weeks of gestation provides evidence that thyroid hormone has a critical role in brain development (1). Infants born preterm have lower serum thyroid hormone levels as compared to term infants, a reflection of reduced thyroid stimulating hormone (TSH) surge following birth, immature postnatal pituitary-thyroid function, and loss of the maternal contribution. Preterm/low birth weight (LBW) infants are at increased risk for co-morbidities, leading to changes in serum thyroid hormone levels typical of non-thyroidal illness syndrome (NTIS), but which may be difficult to separate from central hypothyroidism. To properly interpret thyroid function tests, newborn screening programs need to be cognizant of these perturbations in T4 and TSH levels in preterm/LBW infants. Clinicians who are consulted for evaluation of potential thyroid dysfunction need to be aware of these dynamic changes to make appropriate management decisions. This review will describe fetal and neonatal thyroid physiology, thyroid dysfunction specific to preterm/LBW infants and their impact on newborn screening (NBS) for congenital hypothyroidism, examine treatment studies, and finish with comments on unresolved questions and areas of controversy.

\section{MATERNAL-FETAL THYROID RELATIONSHIPS}

Evidence supports the notion that thyroid hormone present in the fetus in the first trimester is the result of transplacental transfer of maternal hormone (2). This is primarily T4; fetal T3 levels are low as a result of increased placental deiodinase type 3 activity which converts T4 to reverse T3 (RT3). At term, approximately one-third to one-half of cord blood T4 levels are of maternal origin (3). Increased maternal iodine intake during pregnancy is required to keep both mother and fetus iodine sufficient. The recommended dietary allowance (RDA) increases from $150 \mathrm{mcg}$ daily to $250-300 \mathrm{mcg}$ daily with pregnancy (4). As a subgroup, women of reproductive age in the U.S. are borderline iodine deficient (5). Insufficient maternal iodine intake may be a significant factor contributing to lower serum thyroid hormone levels in preterm infants. Maternal hypothyroidism (and maternal iodine deficiency) also are risk factors for preterm birth (6). In addition, excess iodine exposure during pregnancy may also be associated with neonatal hypothyroidism (the Wolff-Chaikoff effect, resulting in temporary decreased production of thyroid hormone). This is a particular problem for preterm/LBW infants, as they are slow

Abbreviations: LBW, low birth weight; VLBW, very low birth weight; L-T4, levothyroxine; NBS, newborn screening; NTIS, non-thyroidal illness syndrome; RDA, recommended daily allowance; RT3, reverse T3; TBG, thyroxine binding globulin; T3, triiodothyronine; T4, thyroxine; TSH, thyroid stimulating hormone. to "escape" from this down regulation and may not recover to normal thyroid hormone production for several weeks. Other drug treatment during pregnancy may also affect neonatal thyroid hormone levels. Treatment with steroids or dopaminergic drugs may decrease TSH secretion, resulting in lower neonatal T4 levels.

\section{MATURATION OF FETAL THYROID FUNCTION}

The thyroid gland starts development at the foramen cecum, migrating to its normal location over the thyroid cartilage. The bilobed thyroid shape is evident by 7 weeks gestation, and thyroid follicles containing colloid are seen histologically by 10 weeks. Thyroglobulin synthesis is detected by 4 weeks, iodine trapping by 8 to 10 weeks, and T4 production by 12 weeks. Significant production of thyroid hormone does not begin until the second trimester (7). Fetal serum T4 concentrations rise from approximately $2 \mathrm{ug} / \mathrm{dl}(26 \mathrm{nmol} / \mathrm{L})$ at 12 weeks to $10 \mathrm{ug} / \mathrm{dL}(128$ $\mathrm{nmol} / \mathrm{L})$ at term $(8,9)$. Parallel changes are seen in fetal serum free $\mathrm{T} 4$ concentrations, rising from approximately $0.1 \mathrm{ng} / \mathrm{dL}(1.3$ $\mathrm{pmol} / \mathrm{L})$ at 12 weeks to $2 \mathrm{ng} / \mathrm{dL}(25.7 \mathrm{pmol} / \mathrm{L})$ at term. As noted above, fetal serum T3 concentrations are low as compared to infant levels, rising from approximately $6 \mathrm{ng} / \mathrm{dL}(0.09 \mathrm{nmol} / \mathrm{L})$ at 12 weeks to $45 \mathrm{ng} / \mathrm{dL}(0.68 \mathrm{nmol} / \mathrm{L})$ at term. Thyrotropin releasing hormone (TRH) is present in hypothalamic neurons by $6-8$ weeks gestation, and TSH secretion can be detected by 12 weeks. Fetal serum TSH concentrations rise from approximately $4 \mathrm{mIU} / \mathrm{L}$ at 12 weeks gestation to $8 \mathrm{mIU} / \mathrm{L}$ at term $(8,9)$. Maturation of the hypothalamic-pituitary-thyroid axis occurs in the second half of gestation, but normal feedback relationships are not mature until term gestation.

\section{POSTNATAL THYROID FUNCTION IN PRETERM/LOW BIRTH WEIGHT INFANTS}

The dramatic rise in serum TSH 30 to 60 minutes following delivery is reduced in preterm infants as compared to term infants, generally in proportion to their degree of prematurity (10). The peak approximates 30 to $50 \mathrm{mIU} / \mathrm{L}$ in preterm infants vs. 60 to 80 $\mathrm{mIU} / \mathrm{mL}$ in term infants (Figure 1). Cord blood T4 levels are lower in infants born preterm, again generally in proportion to the degree of prematurity (Table 1). In response to the dramatic TSH rise, serum T4 and T3 levels are elevated at 24 hours following birth in term infants, gradually falling back to "normal" infant ranges around 5 to 7 days of age. In contrast, in the most preterm infants born at 23 to 27 weeks gestation, serum total T4 levels actually decrease in the first week of life, are "level" in infants born at 28 to 30 weeks gestation, while only those babies born $>30$ weeks gestation show a rise in total T4 in the first week (Figure 2). The differences in total T4 concentrations in term vs. preterm babies is explained by a combination of immature thyroid hormone production from the thyroid gland, decreased binding proteins (primarily thyroxine binding globulin [TBG]) by the liver, 


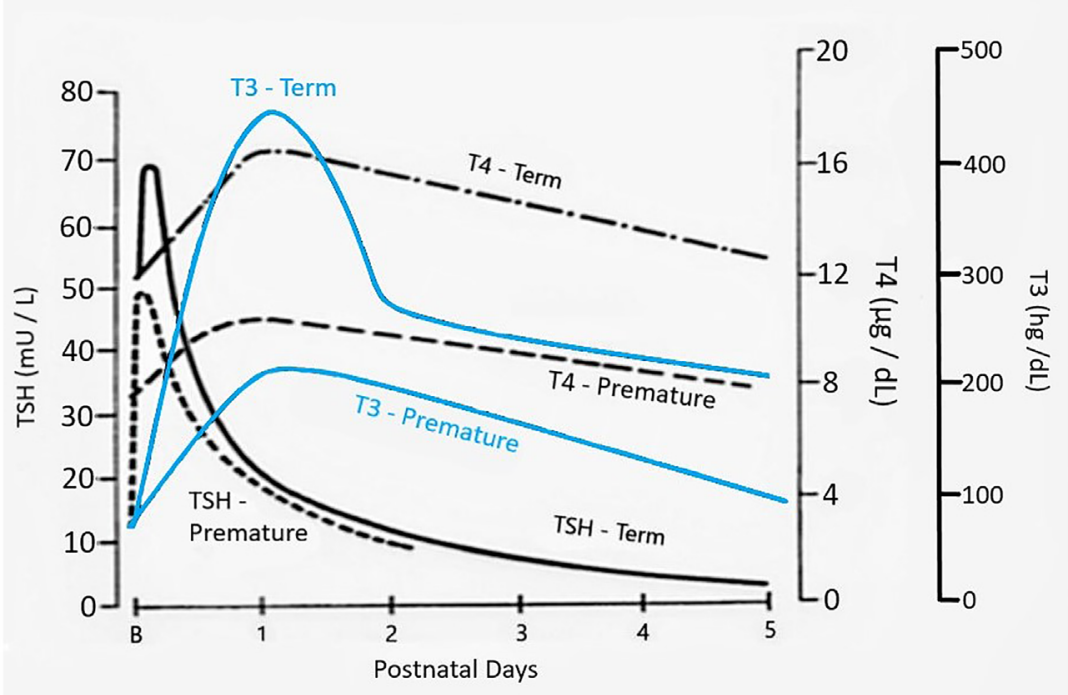

FIGURE 1 | Changes in serum TSH, T4, and T3 following birth in term as compared to preterm newborn infants. Figure developed (with permission) from Fisher DA Thyroid system immaturities in very low birth weight premature infants. Semin Perinatol 2008; 32:387-397.

and the effects of NTIS. Postnatal serum free T4 levels are also lower in the first weeks of life, though proportionally not as low as total T4 levels (Table 1, Figure 3). Serum total T3 levels follow a pattern similar to total $\mathrm{T} 4$, though the levels are proportionally even lower in the most preterm babies, likely a reflection of the impact of NTIS (sometimes referred to as the "low T3 syndrome") (Table 1). Administration of certain drugs used to manage co-morbidities in preterm infants may affect thyroid hormone levels; glucocorticoids and dopaminergic agents may inhibit TSH secretion, while excess iodine may inhibit thyroid hormone production.

\section{UNIQUE PATTERNS OF THYROID DYSFUNCTION IN PRETERM/LOW BIRTH WEIGHT INFANTS}

\section{Hypothyroxinemia of Prematurity}

Serum total T4, and to a lesser extent free $\mathrm{T} 4$ concentrations are decreased in proportion to the degree of prematurity, generally without elevation of serum TSH levels, findings described as "hypothyroxinemia of prematurity". In otherwise healthy preterm infants, serum T4 levels gradually rise, such that by 37

TABLE 1 | Concentrations of free T4, T4, T3, and TSH in preterm and term infants in cord blood at birth, and at 7, 14, and 28 days of age (mean +/- 1 SD).

\begin{tabular}{|c|c|c|c|c|c|}
\hline Gestation (weeks) & Age of Infant & Free T4 (ng/dL) & $\mathrm{T} 4(\mu \mathrm{g} / \mathrm{dL})$ & T3 (ng/dL) & TSH (mU/L) \\
\hline \multirow[t]{4}{*}{ 23-27 weeks } & Cord & $1.28 \pm 0.4$ & $5.4 \pm 2.0$ & $20 \pm 15$ & $6.8 \pm 2.9$ \\
\hline & $7 d$ & $1.47 \pm 0.6$ & $4.0 \pm 1.8$ & $33 \pm 20$ & $3.5 \pm 2.6$ \\
\hline & $14 d$ & $1.45 \pm 0.5$ & $4.7 \pm 2.6$ & $41 \pm 25$ & $3.9 \pm 2.7$ \\
\hline & $28 d$ & $1.50 \pm 0.4$ & $6.1 \pm 2.3$ & $63 \pm 27$ & $3.8 \pm 4.7$ \\
\hline \multirow[t]{4}{*}{ 28-30 weeks } & Cord & $1.45 \pm 0.4$ & $6.3 \pm 2.0$ & $29 \pm 21$ & $7.0 \pm 3.7$ \\
\hline & $7 d$ & $1.82 \pm 0.7$ & $6.3 \pm 2.1$ & $56 \pm 24$ & $3.6 \pm 2.5$ \\
\hline & $14 d$ & $1.65 \pm 0.4$ & $6.6 \pm 2.3$ & $72 \pm 28$ & $4.9 \pm 11.2$ \\
\hline & $28 d$ & $1.71 \pm 0.4$ & $7.5 \pm 2.3$ & $87 \pm 31$ & $3.6 \pm 2.5$ \\
\hline \multirow[t]{4}{*}{ 31-34 weeks } & Cord & $1.49 \pm 0.3$ & $7.6 \pm 2.3$ & $35 \pm 23$ & $7.9 \pm 5.2$ \\
\hline & $7 d$ & $2.14 \pm 0.6$ & $9.4 \pm 3.4$ & $92 \pm 36$ & $3.6 \pm 4.8$ \\
\hline & $14 d$ & $1.98 \pm 0.4$ & $9.1 \pm 3.6$ & $110 \pm 41$ & $3.8 \pm 9.3$ \\
\hline & $28 d$ & $1.88 \pm 0.5$ & $8.9 \pm 3.0$ & $120 \pm 40$ & $3.5 \pm 3.4$ \\
\hline \multirow[t]{4}{*}{$\geq 37$ weeks } & Cord & $1.41 \pm 0.3$ & $9.2 \pm 1.9$ & $60 \pm 35$ & $6.7 \pm 4.8$ \\
\hline & $7 d$ & $2.70 \pm 0.6$ & $12.7 \pm 2.9$ & $148 \pm 50$ & $2.6 \pm 1.8$ \\
\hline & $14 d$ & $2.03 \pm 0.3$ & $10.7 \pm 1.4$ & $167 \pm 31$ & $2.5 \pm 2.0$ \\
\hline & $28 d$ & $1.65 \pm 0.3$ & $9.7 \pm 2.2$ & $176 \pm 32$ & $1.8 \pm 0.9$ \\
\hline
\end{tabular}

T4, thyroxine; T3, triiodothyronine; TSH, thyroid stimulating hormone.

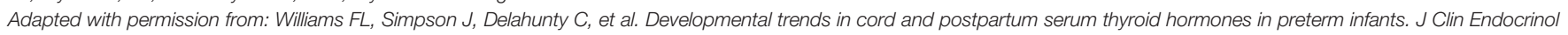
Metab 2004; 89:5314-20 (9). 


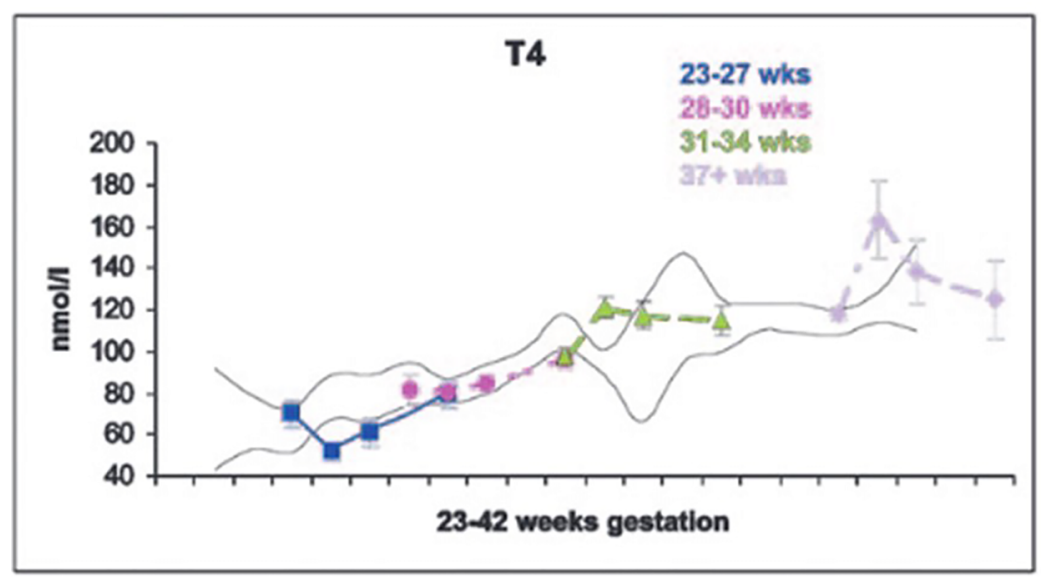

FIGURE 2 | Serum T4 levels in cord blood, and at 7, 14 and 28 days of life in neonates of 23-27, 28-30, 31-34, and 37+ weeks gestation. With permission from Williams FL, Simpson J, Delahunty C, et al. Developmental trends in cord and postpartum serum thyroid hormones in preterm infants. J Clin Endocrinol Metab 2004; 89:5314-5320 (9).

weeks gestation they overlap levels seen in term infants (9). In preterm infants born $<28$ weeks gestation, serum TSH may rise into the 6 to $15 \mathrm{mIU} / \mathrm{L}$ range around 2 to 3 weeks of age (11) (Figure 4), a transient elevation speculated to play a role in stimulating the immature thyroid gland to normal T4 production, so compensating for the loss of maternal T4 contribution. Common co-morbidities associated with preterm birth, such as respiratory distress syndrome, sepsis, intraventricular hemorrhage, etc. are associated with thyroid function tests typical of NTIS: normal or low total T4, low total T3, elevated reverse T3, and normal to low serum TSH (12). Serum free T4 concentrations measured by the more common analog assay method may be low in this setting, while free T4 measured by the more accurate equilibrium dialysis method tends to be in the normal range (13).

\section{Delayed TSH Elevation}

Some preterm/LBW infants manifest serum TSH concentrations greater than the $15 \mathrm{mIU} / \mathrm{L}$ "compensatory" rise described above. The New England NBS program reported an incidence of delayed TSH elevation $>20 \mathrm{mUI} / \mathrm{mL}$ on the dried blood spot of 1:294 VLBW infants (1000-1500 g) and 1:1878 LBW infants (1501-2500 g), as compared to 1:77,280 in term babies ( $>2500 \mathrm{~g})$ (14). The delayed TSH elevation occurred at a peak age of 58 days of life (range 11 to 176 days). In even lower birth weight infants, the Wisconsin NBS program reported an incidence of

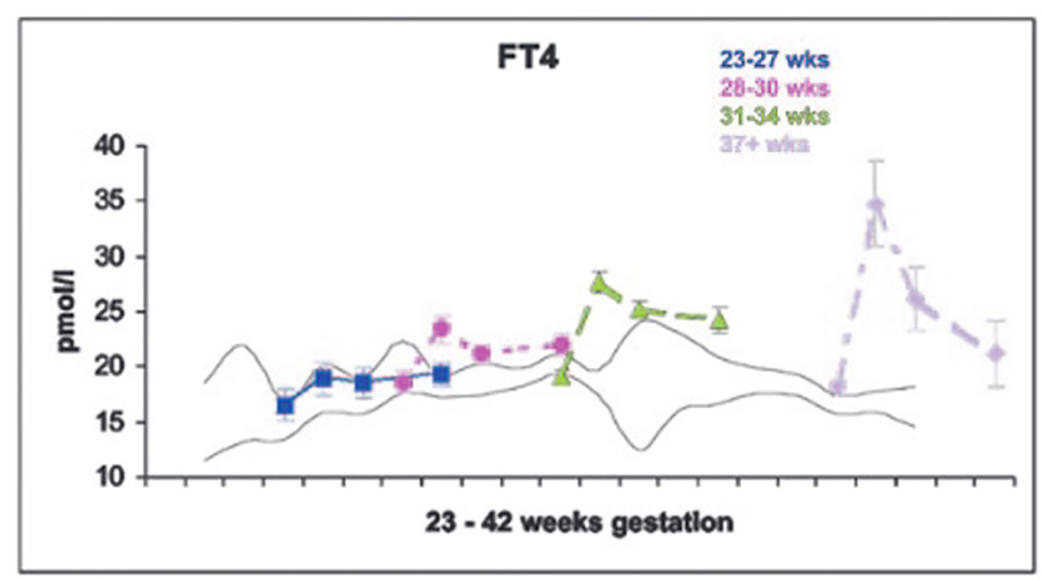

FIGURE 3 | Serum free T4 levels in cord blood, and at 7, 14 and 28 days of life in neonates of 23-27, 28-30, 31-34, and 37+ weeks gestation. With permission from Williams FL, Simpson J, Delahunty C, et al. Developmental trends in cord and postpartum serum thyroid hormones in preterm infants. J Clin Endocrinol Metab 2004; 89:5314-5320 (9). 


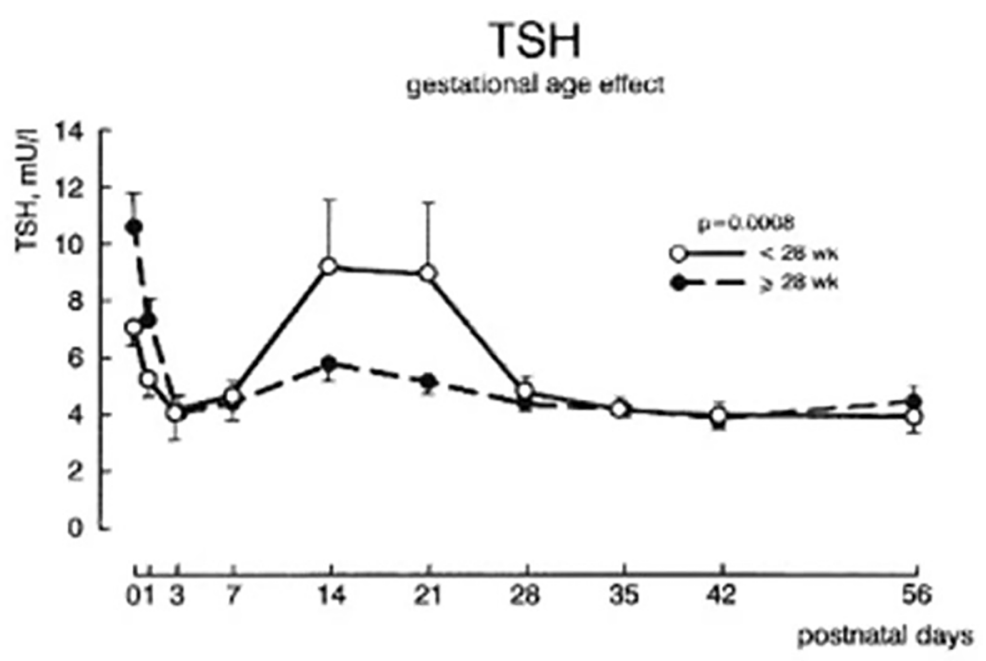

FIGURE 4 | Plasma TSH concentrations \pm SEM during the first 8 weeks after birth in infants of 28-30 week gestation and <28 weeks gestation. With permission from van Wassenaer AG, Kok JH, Dekker FW de Vijlder JJ. Thyroid function in very preterm infants: influences of gestational age and disease. Pediatr Res 1997; 42:604-9 (11).

delayed TSH elevation in 1:13 in babies <500 g, 1:28.5 in babies $500-1000 \mathrm{~g}, 1: 330$ babies 1000-1500 g, and 1:737 babies 1500$2500 \mathrm{~g}$ (15). In infants with higher TSH elevation $>100 \mathrm{mIU} / \mathrm{L}$, the TSH elevation occurred earlier, $\sim 3$ weeks, while those with milder TSH elevation $>20$ mIU/L occurred later, $\sim 8$ weeks of age. Follow-up serum testing has shown that most cases of delayed TSH elevation are transient, particularly if the TSH elevation is mild. In a report from the Rhode Island NBS program, of 19 preterm babies with delayed TSH elevation, three with TSH >50 $\mathrm{mIU} / \mathrm{L}$ were treated with l-thyroxine, while the other 16 infants monitored without treatment recovered to normal thyroid function between 8 and 58 days of life (16).

\section{Role of lodine: Too Little, Too Much}

Although universal salt iodization has greatly improved the status of iodine sufficiency (17), worldwide iodine deficiency remains one of the most common preventable causes of intellectual disability (18). Preterm infants are particularly vulnerable to iodine deficiency, a result of a combination of loss of the maternal contribution, relatively low levels of iodine in preterm formulas, and near absence of iodine in most parenteral nutritional preparations (19). A study of iodine balance in 27 to 30 week gestational age infants showed that they were in negative iodine balance for the first two weeks of life, and they did not reach the $\mathrm{RDA}$ of $30 \mathrm{mcg} / \mathrm{kg} /$ day until 120 days of age (20). Lower iodine intake was correlated with lower serum free T4 and T3 and higher TSH levels. If present, iodine deficiency would be a significant factor contributing to slow recovery from hypothyroxinemia of prematurity.

Exposure to excess iodine has also been demonstrated to cause thyroid dysfunction in preterm infants. Excess iodine results in down regulation of thyroid hormone production (the
Wolff-Chaikoff effect), thought to be a mechanism to protect against development of hyperthyroidism. Normal thyroid function is maintained by "escape" from this down regulation; however, preterm infants are slow to escape and so may become hypothyroid. Common sources of iodine exposure include iodinated contrast agents and topical iodine antiseptics. Infants with congenital heart disease (CHD) are frequently exposed to such sources; in a study of 183 infants with $\mathrm{CHD}$, one-quarter manifested elevation of serum TSH levels, ranging from 9 to $>100 \mathrm{mIU} / \mathrm{mL}$ (21). About half were treated with thyroid hormone, while others recovered to euthyroidism after discontinuation of excess iodine exposure. This study involved primarily term infants; likely the effect of excess iodine would apply to preterm/LBW infants.

\section{Impact of Preterm Birth/Low Birth Weight on Newborn Screening for Congenital Hypothyroidism}

Several NBS programs from Europe and North America report that the incidence of congenital hypothyroidism is higher in preterm infants. As compared to an incidence of approximately $1: 1,500$ to $1: 2,000$ in term infants $(22,23)$, the incidence in preterm infants approximates 1:900 (24). The incidence is even higher in NBS programs that undertake repeat screening in preterm babies, from 1:300 in LBW to 1:50 in VLBW babies $(14,16)$.

In NBS programs that employ a primary T4-reflex TSH test strategy, preterm/LBW infants make up a higher percentage of cases that fall below the T4 cutoff (typically the $10^{\text {th }}$ percentile), while the screening TSH is not elevated. These NBS programs must then decide whether to follow-up cases with low T4-nonelevated TSH levels. In some programs, lack of an abnormal TSH 
elevation is the end of screening. However, most NBS programs now collect a 2 nd dried blood specimen at 2 to 4 weeks of life in infants born $<32$ weeks gestation or $<1500 \mathrm{~g}$ birth weight (25). In the very preterm babies $<28$ weeks gestation, several NBS programs collect a $3^{\text {rd }}$ dried blood specimen at 6 to 8 weeks of life, which is typically around 37 weeks or term gestation. In the majority of preterm/LBW babies, the screening T4 will reach the range seen in term infants by the $2^{\text {nd }}$ or $3^{\text {rd }}$ specimen (5). Collection of the $2^{\text {nd }}$ and $3^{\text {rd }}$ specimens allows detection of preterm babies with delayed TSH elevation, described above.

A few preterm infants will not normalize total T4 by term gestation; such results could be explained by low binding protein levels or NTIS, although central hypothyroidism cannot be ruled out. In these cases, NBS programs recommend serum thyroid function tests, including TSH, total and free T4. In the presence of low binding proteins or NTIS, serum free T4 is most accurately measured by equilibrium dialysis. A normal free T4 and TSH rule out hypothyroidism, while a low free T4 and low or normal range TSH is compatible with central hypothyroidism, leading to evaluation for other pituitary hormone deficiencies. Such cases in preterm infants are rare, likely with an incidence matching term infants:!:25,000 (26).

In NBS programs that employ a primary TSH test approach, otherwise healthy preterm babies will fall below the dried blood TSH cutoff, typically $<25 \mathrm{mIU} / \mathrm{L}$ (serum units). As described for T4-reflex TSH test programs, most primary TSH test programs collect a 2 nd dried blood specimen at 2 to 4 weeks of life in infants born $<32$ weeks gestation or $<1500 \mathrm{~g}$ birth weight, and many collect a $3^{\text {rd }}$ dried blood specimen at 6 to 8 weeks of life in preterm babies born $<28$ weeks gestation. Collection of the $2^{\text {nd }}$ and $3^{\text {rd }}$ specimens allows detection of preterm babies with delayed TSH elevation, whereas stopping screening with a normal TSH on the $1^{\text {st }}$ test risks missing infants with delayed TSH elevation. Re-evaluation after age 2 to 3 years of age shows that many have transient hypothyroidism (27-29).

\section{Unique patterns of Thyroid Dysfunction in Preterm/Low Birth Weight Infants: Physiologic or Pathologic?}

Preterm/LBW infants manifest clinical features that might be ascribed to thyroid dysfunction, such as temperature instability, apnea with immature pulmonary function and low surfactant levels, bradycardia, slow to feed with sluggish gut motility, edema, hypotonia, and slow growth and development. Several observational studies demonstrate a correlation between low serum T4 levels and these clinical manifestations (30, 31). As these babies typically have low serum T4-non-elevated TSH levels, clinicians face the dilemma as to whether these features are caused by central hypothyroidism and so might improve with thyroid hormone treatment. However, randomized, placebocontrolled trials using either T4 or a combination of T4 and T3 generally do not show an effect on objective measures, such as O2 requirements, incidence of respiratory distress syndrome, requirement for inotropic agents, progression from parenteral to oral feedings, weight gain, length, or head circumference measurements, or on mortality (32-34). A Cochrane Database Review in 2007 also found no benefit of thyroid hormone treatment in this situation (35).

A more compelling question asks whether deficits in neurodevelopment in preterm infants are a consequence of the hypothyroxinemia. Several studies report an increased odds ratio for endpoints such as disabling cerebral palsy (36), reduced attention span (37), vision disturbances (38), and overall lower IQ (39). However, owing to "confounding variables" common to preterm infants, it is difficult to establish a causal relationship with the hypothyroxinemia alone. In a study of preterm infants $<1500 \mathrm{~g}$, a comparison of outcome in infants with and without hypothyroxinemia did not find any significant differences in neurodevelopmental, vision or hearing impairment at 5 years of age (40).

What about treatment trials? A randomized, placebocontrolled trial of T4 treatment in 200 infants less than 30 weeks gestational age with multiple assessments of neurodevelopment over time was carried out by the Dutch. Half were treated with $1-\mathrm{T} 48 \mathrm{mcg} / \mathrm{kg} / \mathrm{d}$, half with placebo for the first 6 weeks of life. In the first assessment at 24 months of age, there were no differences in the Bayley Infant Scales of Mental and Motor Development (41). However, subgroup analysis showed that the Bayley Mental Developmental Index (MDI) score was 18 points higher in the T4-treated group $\leq 27$ weeks gestation, $(\mathrm{p}<.05)$, but 10 points lower in the T4-treated group $\geq 27$ weeks gestation (42) (Table 2). Re-evaluation at school age (5.7 years) showed that the MDI score had narrowed to 10 points, now not statistically significant (43). Survey of study families at 10 years of age showed that in subjects $\leq 27$ weeks gestation treated with $\mathrm{T} 4$, there was a trend toward a lower percentage needing special education, whereas in subjects at 29 weeks gestation, the opposite was true, though only the latter reached statistical significance (Table 2 ). In subjects $\leq 28$ weeks gestation treated with T4, again there was a trend toward better motor outcome as compared to control subjects, but this difference did not reach statistical significance (44). To try and resolve the question of potential benefit in infants born $<28$ weeks, a more recent trial of thyroid supplementation was undertaken in Amsterdam, Madrid and New York (45). This trial included six treatment arms to investigate different modalities of thyroid hormone administration, combination T4 and $\mathrm{T} 3$ treatment, one iodine treatment arm, and one placebo arm. Testing at 36 months of age did not find any differences in neurodevelopmental index scores among the eight groups (Table 2). Finally, in a double-blind, randomized, placebocontrolled trial in preterm babies $<28$ weeks gestation from the United Kingdom, evaluation at 42 months by the Bayley III Mental and Psychomotor Developmental Indices showed statistically better motor, language, and cognitive domains in the group treated with thyroid hormone (46). In summary, the randomized, placebo-controlled trials show mixed results, with potentially some benefit of T4 treatment in infants $<28$ weeks but potential harm in infants $>28$ weeks gestation. 
TABLE 2 | Summary of studies investigating I-T4 treatment v placebo on neurocognitive outcome in preterm infants.

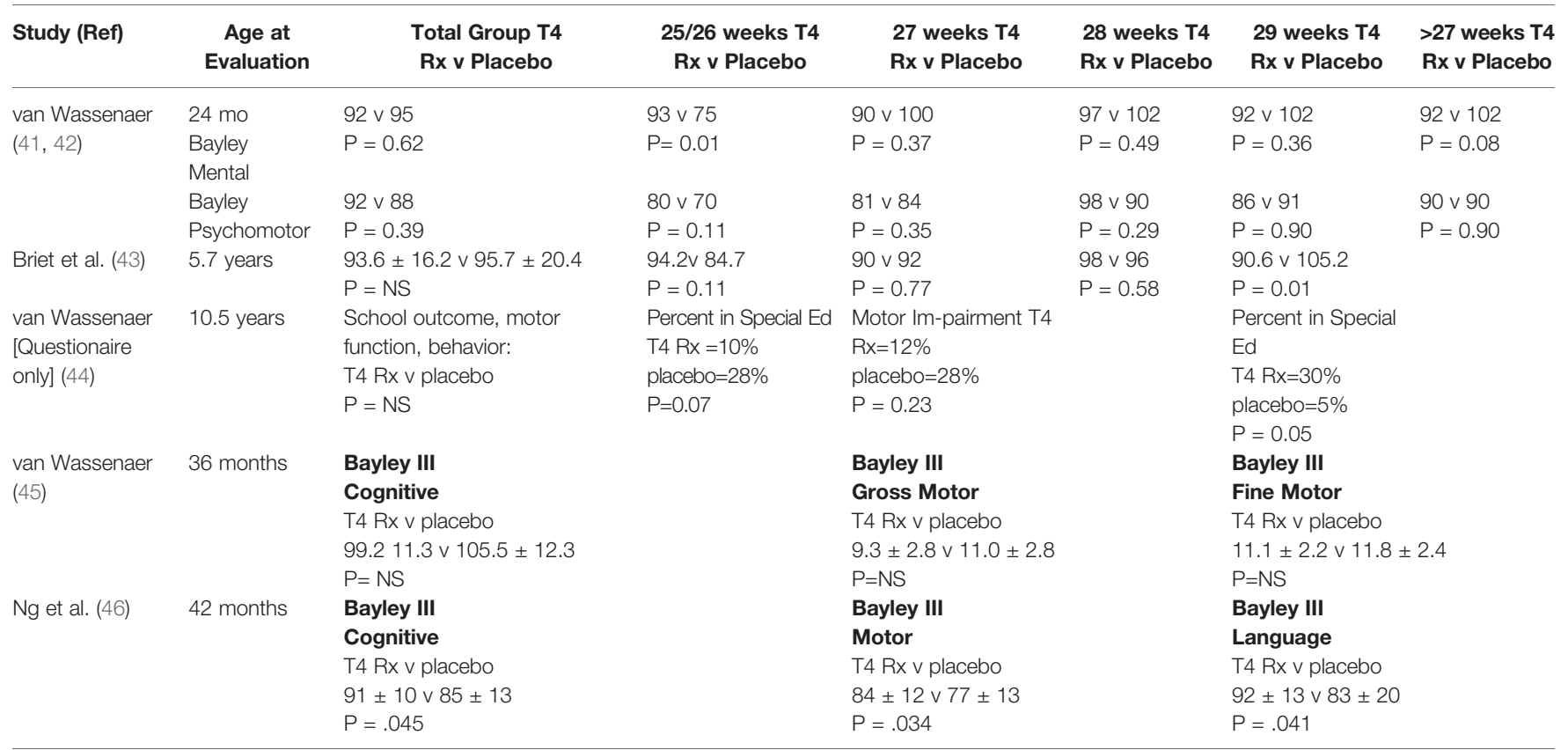

T4 Rx, l-thyroxine treated group.

NS, non-significant.

\section{CONCLUSION: UNRESOLVED QUESTIONS AND AREAS OF CONTROVERSY}

Much has been learned over the last few decades about fetal and neonatal thyroid physiology; thyroid function is different in babies born preterm/LBW as compared to term infants. As such, there remain unresolved questions and areas of controversy regarding management of thyroid issues in preterm infants. The following section highlights a few of these areas.

\section{At What Gestational Age Can the Postnatal HPT Axis Compensate for Loss of Maternal T4 Quickly Enough to Avert Untoward Effects of Thyroid Hormone Deficiency?}

A reasonable goal for serum T4 or free T4 levels after birth in preterm babies might be to either match in utero concentrations present at a similar gestational age or levels in term infants by 1-2 weeks after birth. Evidence suggests that infants born $<28$ weeks gestation have serum T4 (and to a lesser extent free T4) concentrations that take up to 4 to 6 weeks to overlap the range seen in term infants. The transient rise in serum TSH to the 6-15 $\mathrm{mU} / \mathrm{L}$ range between 2 and 4 weeks of age in babies born $<28$ weeks gestation (but not in babies $\geq 28$ weeks gestation) supports the notion that the thyroid gland in babies born $<28$ weeks gestation requires increased TSH stimulation to normalize thyroid hormone production. Slow recovery of normal thyroid physiology might impact any organ system, e.g., maturation of lung function, but most importantly it could impact neurodevelopment.

\section{Should lodine Supplementation Be Routine in Preterm Infants?}

Most preterm infant formulas do not contain enough iodine to allow these babies to meet the RDA of $30 \mathrm{mcg} \mathrm{I} / \mathrm{kg} / \mathrm{d}$, and many parenteral nutritional preparations lack iodine completely. A recent Cochrane database review did not show benefit of iodine supplementation in preterm infants on morbidity, mortality, or neurodevelopmental outcome (47). Despite this report, given the known effect of iodine to prevent "endemic cretinism", routine supplementation of preterm formulas and parenteral nutritional preparations would seem important to achieve T4 production matching term infants. Sufficient iodine intake is equally important for nursing mothers. At the same time, care should be taken to avoid exposure to excess iodine.

\section{Do Infants With "Delayed TSH Elevation" Benefit From Detection and Treatment?}

Studies show that the majority of preterm babies with delayed TSH elevation will recover to normal TSH levels without treatment. However, the average age at peak TSH elevation is approximately 8 weeks, with a range from 11 to 176 days of life (14). The TSH elevation likely reflects inadequate thyroid hormone production. Although babies recover to normal thyroid function, are there consequences from low T4 levels, present over several weeks? Few studies have been carried out to address this issue. The study from Rhode Island showed 
developmental scores were similar to control infants, although the incidence of infants with head circumference $<10^{\text {th }}$ percentile was higher in the delayed TSH elevation group (16). It would seem prudent to treat infants with elevated serum TSH and low free T4 levels until recovery to normal thyroid function; since this is difficult to judge without stopping l-thyroxine, most babies are treated until age 2-3 years and then re-evaluated.

\section{Does T4 Treatment Improve Morbidity/ Mortality and Neurodevelopmental Outcome in Preterm Infants <28 Weeks Gestation?}

While it is difficult to separate out the effects of co-morbidities from hypothyroxinemia on neurodevelopmental outcome, there are now two randomized, placebo controlled trials in preterm infants $<28$ weeks gestation that report higher scores in the T4treated group $(42,46)$. As noted above, there may be some "physiological" support for this finding, as thyroid function in

\section{REFERENCES}

1. Bernal J, Pekonen F. Ontogenesis of the Nuclear 3,5,3'-Triiodothyronine Receptor in the Human Fetal Brain. Endocrinology (1984) 114:677-9. doi: 10.1210/endo-114-2-677

2. Obregon MJ, Calvo RM, Del Rey FE, de Escobar GM. Ontogenesis of Thyroid Function and Interactions With Maternal Function. Endocr Dev (2007) 10:86. doi: $10.1159 / 000106821$

3. Vulsma T, Gons MH, de Vijlder JJ. Maternal-Fetal Transfer of Thyroxine in Congenital Hypothyroidism Due to A Total Organification Defect or Thyroid Agenesis. N Engl J Med (1989) 321:13. doi: 10.1056/NEJM198907063210103

4. Alexander EK, Pearce EN, Brent GA, Brown RS, Chen H, Dosiou C, et al. 2017 Guidelines of the American Thyroid Association for the Diagnosis and Management of Thyroid Disease During Pregnancy and the Postpartum. Thyroid (2017) 27:315. doi: 10.1089/thy.2016.0457

5. Herrick KA, Perrine CG, Aoki Y, Caldwell KL. Iodine Status and Consumption of Key Iodine Sources in the U.S. Population With Special Attention to Reproductive Age Women. Nutrients (2018) 10:874. doi: $10.3390 /$ nu10070874

6. Sheehan PM, Nankervis A, Araujo Júnior E, Da Silva Costa F. Maternal Thyroid Disease and Preterm Birth: Systematic Review and Meta-Analysis. J Clin Endocrinol Metab (2015) 100:4325-31. doi: 10.1210/jc.2015-3074

7. Thorpe-Beeston JG, Nicolaides KH, McGregor AM. Fetal Thyroid Function. Thyroid (1992) 2:207. doi: 10.1089/thy.1992.2.207

8. Thorpe-Beeston JG, Nicolaides KH, Felton CV, Butler J, McGregor AM. Maturation of the Secretion of Thyroid Hormone and Thyroid-Stimulating Hormone in the Fetus. N Engl J Med (1991) 324:532. doi: 10.1056/ NEJM199102213240805

9. Williams FL, Simpson J, Delahunty C, Ogston SA, Bongers-Schokking JJ, Murphy N, et al. Developmental Trends in Cord and Postpartum Serum Thyroid Hormones in Preterm Infants. J Clin Endocrinol Metab (2004) 89:5314. doi: 10.1210/jc.2004-0869

10. Murphy N, Hume R, van Toor H, Matthews TG, Ogston SA, Wu S-Y, et al. The Hypothalamic-Pituitary-Thyroid Axis in Preterm Infants; Changes in the First 24 Hours of Postnatal Life. J Clin Endocrinol Metab (2004) 89:2824. doi: 10.1210/jc.2003-030317

11. Van Wassenaer AG, Kok JH, Dekker FW, de Vijlder JJ. Thyroid Function in Very Preterm Infants: Influences of Gestational Age and Disease. Pediatr Res (1997) 42:604-9. doi: 10.1203/00006450-199711000-00009

12. Simpson J, Williams FL, Delahunty C, van Toor H, Wu S-Y, Ogston SA, et al. Serum Thyroid Hormones in Preterm Infants and Relationships to Indices of infants born $<28$ weeks gestation may be too immature to quickly replace the lost maternal thyroid hormone contribution. That said, the follow-up studies by the Dutch showed that the higher neurodevelopmental scores in the treated group tended to approach the placebo group over time (44). While the more recent trial from Amsterdam, Madrid, and New York did not show benefit of thyroid hormone treatment, the investigators cautioned that "power was insufficient to detect any but very large differences". With these mixed results, as the saying goes, more randomized controlled trials are needed before such treatment becomes standard of care.

\section{AUTHOR CONTRIBUTIONS}

SL undertook focused literature review and writing of the manuscript.
Severity of Intercurrent Illness. J Clin Endocrinol Metab (2005) 90:1271. doi: 10.1210/jc.2004-2091

13. Deming DD, Rabin CW, Hopper AO, Peverini RL, Vyhmeister NR, Nelson JC. Direct Equilibrium Dialysis Compared With Two Non-Dialysis Free T4 Methods in Premature Infants. J Pediatr (2007) 151:404. doi: 10.1016/ j.jpeds.2007.03.046

14. Mandel SJ, Hermos RJ, Larson CA, Prigozhin AB, Rojas DA, Mitchell ML. Atypical Hypothyroidism and the Very Low Birthweight Infant. Thyroid (2000) 10:693. doi: 10.1089/10507250050137770

15. Kaluarachchi DC, Allen DB, Eickhoff JC, Dawes JT, Baker MW. Increased Congenital Hypothyroidism Detection in Preterm Infants With Serial Newborn Screening. J Pediatr (2019) 207:220. doi: 10.1016/j.jpeds.2018.11.044

16. Woo HC, Lizarda A, Tucker R, Mitchell ML, Vohr B, Oh W, et al. Congenital Hypothyroidism With a Delayed Thyroid-Stimulating Hormone Elevation in Very Premature Infants: Incidence and Growth and Developmental Outcomes. J Pediatr (2011) 158:538. doi: 10.1016/j.jpeds.2010.10.018

17. Lazarus JH. Role of the Iodine Global Network in Elimination of Iodine Deficiency. Recent Pat Endor Metab Immune Drug Discovery (2017) 10:11922. doi: $10.2174 / 1872214811666170330152202$

18. Cao XY, Jiang XM, Dou ZH, Rakeman MA, Zhang ML, O’Donnell K, et al. Timing of Vulnerability of the Brain to Iodine Deficiency in Endemic Cretinism. N Engl J Med (1994) 331(26):1739-44. doi: 10.1056/ NEJM199412293312603

19. Belfort MB, Pearce EN, Braverman LE, He X, Brown RS. Low Iodine Content in the Diets of Hospitalized Preterm Infants. J Clin Endocrinol Metab (2012) 97:E632-6. doi: 10.1210/jc.2011-3369

20. Ares S, Escobar-Morreale HF, Quero J, Durán S, Presas MJ, Herruzo R, et al. Neonatal Hypothyroxinemia: Effects of Iodine Intake and Premature Birth. J Clin Endocrinol Metab (1997) 82:1704-12. doi: 10.1210/jcem.82.6.4019

21. Thaker VV, Galler MF, Marshall AC, Almodovar MC, Hsu H-W, Addis CJ, et al. Hypothyroidism in Infants With Congenital Heart Disease Exposed to Excess Iodine. J Endocrin Soc (2017) 1:1067-78. doi: 10.1210/js.2017-00174

22. Hinton CF, Harris KB, Borgfeld L, Drummond-Borg M, Eaton R, Lorey F, et al. Trends Incidence Rates of Congenital Hypothyroidism Related to Select Demographic Factors: Data From the United States, California, Massachusetts, New York, and Texas. Pediatrics (2010) 125:Suppl 2:S37-47. doi: 10.1542/peds.2009-1975D

23. Corbetta C, Weber G, Cortinovis F, Calebrio D, Passoni A, Vigone MC, et al. A 7-Year Experience With Low Blood TSH Cutoff Levels for Neonatal Screening Reveals an Unsuspected Frequency of Congenital Hypothyroidism (CH). Clin Endocrinol (2009) 71:739-45. doi: 10.1111/j.1365-2265.2009.03568.x 
24. Cavarzere P, Camilot M, Popa FI, Lauriola S, Teofoli F, Gaudino R, et al. Congenital Hypothyroidism With Delayed TSH Elevation in Low-BirthWeight Infants: Incidence, Diagnosis and Management. Eur J Endocrinol (2016) 175:395-402. doi: 10.1530/EJE-15-1233

25. van Trotsenburg AS, Stoupa A, Léger J, Rohrer T, Peters C, Fuggazzola L, et al. Congenital Hypothyroidism: A 2020 Consensus Guidelines Update An ENDOEUROPEAN REFERENCE NETWORK (ERN) Initiative Endorsed by the European Society for Pediatric Endocrinology and the European Society for Endocrinology. Thyroid (2021) 31:387-419. doi: 10.1089/thy.2020.0333

26. Naafs JC, Verkerk JC, Fliers E, van Trotsenburg ASP, Zwaveling-Soonawala N. Clinical and Genetic Characteristics of Dutch Children With Central Congenital Hypothyroidism, Early Detected by Neonatal Screening. Eur J Endocrinol (2020) 183:627-36. doi: 10.1530/EJE-20-0833

27. Mitchell ML, Hsu H-W, Sahai I. And the Massachusetts Pediatric Endocrine Work Group. The Increased Incidence of Congenital Hypothyroidism: Fact or Fancy? Clin Endocrinol (2011) 75:806-10. doi: 10.1111/j.13652265.2011.04128.x

28. Srinivasan R, Harigopal S, Turner S, Cheetham T. Permanent and Transient Congenital Hypothyroidism in Preterm Infants. Acta Paediatr (2012) 101 : e179-82. doi: 10.1111/j.1651-2227.2011.02536.x

29. Vigone MC, Caiulo S, Di Fenna M, Ghirardello S, Corbetts C, Mosca F, et al. Evolution of Thyroid Function in Preterm Infants Detected by Screening for Congenital Hypothyroidism. J Pediatr (2014) 164:1296-302. doi: 10.1016/ j.jpeds.2013.12.048

30. Hadeed AJ, Asay LD, Klein AH, Fisher DA. Significance of Transient Postnatal Hypothyroxinemia in Premature Infants With and Without Respiratory Distress Syndrome. Pediatrics (1981) 68:494.

31. Mercado M, Szymonowicz W, Yu VY, Gold H. Symptomatic Hypothyroxinemia With Normal TSH Levels in Preterm Infants. Clin Pediatr (Phila) (1987) 26:343. doi: 10.1177/000992288702600704

32. Chowdhry P, Scanlon JW, Auerbach R, Abbassi V. Results of Controlled Double-Blind Study of Thyroid Replacement in Very Low-Birth-Weight Premature Infants With Hypothyroxinemia. Pediatrics (1984) 73:301.

33. Ng SM, Turner MA, Gamble C, Didi M, Victors S, Manning D, et al. An Explanatory Randomized Placebo Controlled Trial of Levothyroxine Supplementation for Babies Born <28 Weeks' Gestation: Results of the TIPIT Trial. Trials (2013) 14:211. doi: 10.1186/1745-6215-14-211

34. Valerio PG, van Wassenaer AG, de Vijlder JJ, Kok JH. A Randomized, Masked Study of Triiodothyronine Plus Thyroxine Administration in Preterm Infants Less Than 28 Weeks of Gestational Age: Hormonal and Clinical Effects. Pediatr Res (2004) 55:248. doi: 10.1203/01.PDR.0000104153.72572.F5

35. Osborn DA, Hunt RW. Prophylactic Postnatal Thyroid Hormones for Prevention of Morbidity and Mortality in Preterm Infants. Cochrane Database Syst Rev (2007), CD005948. doi: 10.1002/14651858.CD005948.pub2

36. Reuss ML, Paneth N, Pinto-Martin JA, Lorenz JM, Susser M. The Relation of Transient Hypothyroxinemia in Preterm Infants to Neurologic Development At Two Years of Age. N Engl J Med (1996) 334:821. doi: 10.1056/ NEJM199603283341303

37. Simic N, Asztalos EV, Rovet J. Impact of Neonatal Thyroid Hormone Insufficiency and Medical Morbidity on Infant Neurodevelopment and Attention Following Preterm Birth. Thyroid (2009) 19:395. doi: 10.1089/thy.2008.0282
38. Simic N, Westall C, Astzalos EV, Rovet J. Visual Abilities at 6 Months in Preterm Infants: Impact of Thyroid Hormone Deficiency and Neonatal Medical Morbidity. Thyroid (2010) 20:309. doi: 10.1089/thy.2009.0128

39. Den Ouden AL, Kok JH, Verkerk PH, Brand R, Verloove-Vanhorick SP. The Relation Between Neonatal Thyroxine Levels and Neurodevelopmental Outcome at Age 5 and 9 Years in a National Cohort of Very Preterm and/ or Very Low Birth Weight Infants. Pediatr Res (1996) 39:142. doi: 10.1203/ 00006450-199601000-00021

40. Tan LO, Tan MG, Poon WB. Lack of Association Between Hypothyroxinemia of Prematurity and Transient Thyroid Abnormalities With Adverse LongTerm Neurodevelopmental Outcome in Very Low Birth Weight Infants. PloS One (2019) 14:e0222018. doi: 10.1371/journal.pone.0222018

41. van Wassenaer AG, Kok JH, de Vijlder JJ, Briet JM, Smit BJ, Tamminga P, et al. Effects of Thyroxine Supplementation on Neurologic Development in Infants Born at Less Than 30 Weeks' Gestation. N Engl J Med (1997) 336:21. doi: 10.1056/NEJM199701023360104

42. Van Wassenaer AG, Kok JH, Briët JM, van Baer AL, De Vijlder JJ. Thyroid Function in Preterm Newborns; Is T4 Treatment Required in Infants $<27$ Weeks' Gestational Age? Exp Clin Endocrinol Diabetes (1997) 105 Suppl 4:12. doi: $10.1055 / \mathrm{s}-0029-1211925$

43. Briët JM, van Wassenaer AG, Dekker FW, de Vijlder JJ, van Baer A, Kok JH. Neonatal Thyroxine Supplementation in Very Preterm Children: Developmental Outcome Evaluated at Early School Age. Pediatrics (2001) 107:712. doi: 10.1542/peds.107.4.712

44. van Wassenaer AG, Westera J, Houtzager BA, Kok JH. Ten-Year Follow-Up of Children Born at <30 Weeks' Gestational Age Supplemented With Thyroxine in the Neonatal Period in A Randomized, Controlled Trial. Pediatrics (2005) 116:e613. doi: 10.1542/peds.2005-0876

45. van Wassenaer-Leemhuis A, Ares S, Golombek G, Kok J, Paneth N, Kase J, et al. Thyroid Hormone Supplementation in Preterm Infants Born Before 28 Weeks Gestational Age and Neurodevelopmental Outcome at Age 36 Weeks. Thyroid (2014) 24:1162-9. doi: 10.1089/thy.2013.0618

46. Ng SM, Turner MA, Weindling M. Neurodevelopmental Outcomes at 42 Months After Thyroxine Supplementation in Infants Below 28 Weeks' Gestation: A Randomized Controlled Trial. Thyroid (2020) 30:948. doi: 10.1089/thy.2019.0293

47. Walsh V, Brown JVE, McGuire W. Iodine Supplementation for the Prevention of Mortality and Adverse Neurodevelopmental Outcomes in Preterm Infants. Cochrane Database Systemic Rev (2019) 2(2):CD005253. doi: 10.1002/14651858.CD005253.pub3

Conflict of Interest: The author declares that the research was conducted in the absence of any commercial or financial relationships that could be construed as a potential conflict of interest.

Copyright $\odot 2021$ LaFranchi. This is an open-access article distributed under the terms of the Creative Commons Attribution License (CC BY). The use, distribution or reproduction in other forums is permitted, provided the original author(s) and the copyright owner(s) are credited and that the original publication in this journal is cited, in accordance with accepted academic practice. No use, distribution or reproduction is permitted which does not comply with these terms. 